\title{
Sleep problems related to the influence of pain and quality of life in patients with temporomandibular dysfunction.
}

\section{Problemas relacionados ao sono e influência da dor na qualidade de vida em pacientes com disfunção temporomandibular.}

\author{
Chaiane Facco Piccin', Daniela Pozzebon', Eliane Castilhos Rodrigues Corrêa².
}

\begin{abstract}
Introduction: Sleep is an inherent condition of life itself, and the physical and mental health is associated with an efficient sleep which in turn contributes to a good quality of life. Objective: To analyze the association between reports of sleep-related problems and the impact of pain on quality of life, and the frequency of reporting nocturnal oral parafunction in patients with dysfunction temporomandibular. Method: 32 subjects with a diagnosis of dysfunction temporomandibular through protocol "Research Diagnostic Criteria for Temporomandibular Disorders", were evaluated with the analysis of the association of issues related to the influence of pain on quality of life and sleep-related problems and nocturnal oral parafunction. Results: There was a significant positive relation between the quality of sleep (difficulty falling asleep, waking up at dawn and restless or disturbed sleep) and the influence of pain on quality of life of individuals with dysfunction temporomandibular (interference with daily activities, willingness to participate in leisure, social and family activities and the ability to work) on most issues evaluated. As the nocturnal oral parafunction, $90.62 \%$ of the subjects complained of squeaks and/or clenching of the teeth during sleep, and $78.13 \%$ reported feeling tired or sore jaw upon waking in the morning. Conclusion: It can be concluded that the greater the occurrence of problems related to sleep, the higher the impact of pain on quality of life of patients with dysfunction temporomandibular. Also there was a high frequency of nocturnal parafunctional habits in the evaluated patients.
\end{abstract}

Keywords: Quality of Life; Sleep; Pain.

\section{RESUMO}

Introdução: O sono é uma condição inerente da própria vida, sendo que a saúde física e mental está associada a um sono eficiente que, por sua vez, contribui para uma boa qualidade de vida. Objetivo: Analisar a associação entre relatos de problemas relacionados ao sono e da influência da dor na qualidade de vida, bem como a frequência do relato de parafunção oral noturna em pacientes com disfunção temporomandibular. Método: Foram avaliados 32 sujeitos com diagnóstico de disfunção temporomandibular por meio do protocolo "Critérios Diagnósticos para Pesquisa em Disfunções Temporomandibulares", com a análise da associação de questões referentes à influência de dor na qualidade de vida e de problemas relacionados ao sono e parafunção oral noturna. Resultados: Houve relação significante positiva entre a qualidade de sono (dificuldade em adormecer, acordar de madrugada e sono agitado ou perturbado) e a influência de dor na qualidade de vida dos sujeitos com disfunção temporomandibular (interferência nas atividades diárias, disposição de participar de atividades de lazer, sociais e familiares e capacidade de trabalhar) na maioria das questões avaliadas. Quanto ao relato de parafunção oral noturna, 90,62\% dos sujeitos apresentaram queixas de rangidos e/ou apertamento dos dentes durante o sono e $78,13 \%$ relataram sensação de mandíbula cansada ou dolorida ao acordar pela manhã. Conclusão: Pode-se concluir que quanto maior a ocorrência de problemas relacionados ao sono, maior a influência da dor na qualidade de vida dos pacientes com disfunção temporomandibular. Também verificou-se uma alta frequência de hábitos parafuncionais noturnos nos pacientes avaliados.

Palavras-chave: Qualidade de Vida; Sono; Dor. 


\section{INTRODUCTION}

The good quality of sleep is intrinsically important to maintain physical functioning and psychic well-being. ${ }^{(1)}$ Sleep is an inherent condition of their lives, and the physical and mental health is associated with an efficient sleep which in turn contributes to a good quality of life. ${ }^{(2)}$

Temporomandibular disorder (TMD) is characterized by functional changes of temporomandibular joint (TMJ) and/or muscles of mastication, being multifactorial etiology. The triggering and perpetuation of TMD are conditioned to the interaction of factors such as trauma, ligamentous laxity, parafunctional habits, stress, systemic diseases, among others. (3-5) The parafunctional habits such as grinding or clenching habits are considered important within the etiological factors of TMD. Are habits that affects the implementation of the normal functions of the stomatognathic system, which can occur during sleep or waking. ${ }^{(6,7)}$

It is frequently associated with TMD often psychological and somatic complaints, including fatigue, sleep disturbances, anxiety and depression. ${ }^{(8,9)}$ Patients with TMD have reported difficulty sleeping, waking up at dawn and present agitated or disturbed sleep, and these conditions are provided sleep disorders such as obstructive sleep apnea and insomnia. ${ }^{(10,11)}$

Due to the physical and mental impairment caused by TMD, evaluation of the impact on quality of life of these patients deserve special attention. TMD patients have clinical characteristics in common with people with other chronic diseases such as high levels of pain intensity, behavioral and psychological disorders. ${ }^{(12)}$ The significant number of patients with TMD and diversity of the symptoms presented by them as well as its impact on quality of life, it required an adequate knowledge of the disease and careful study for their correct treatment. ${ }^{(13,14)}$

There is not a reciprocal relationship between quality of sleep and pain, ${ }^{(15)}$ however, examines the hypothesis that the deprivation or sleep disturbance increases the tenderness and causes pain. The pain disrupts sleep inducing awakenings and causing all other neurobiological consequences of stress, which are incompatible with a peaceful sleep. Thus, arising a continuous cycle initiated by sleep disorders or pain, wherein the two components maintains or increases the other. ${ }^{(16)}$

Given the above, this study aimed to analyze the association between reports of problems related to sleep and the influence of pain on quality of life, and the frequency of nocturnal oral parafunction reported in patients with TMD.

\section{METHOD}

The study was conducted in Orofacial Motricity Laboratory by the Speech Therapy Service of the home institution. The project was approved by the home institution of the Research Ethics Committee CAAE: 33665714.0.0000.5346/2014), according to the Resolution 466/2012 of the National Health Council.
Participants were recruited from individuals seeking treatment at dental clinics, orofacial pain clinics or TMD and among those who attended the dissemination of research in print and electronic media. They included subjects of both genders, aged 18 to 40 diagnosed with TMD, obtained by the Diagnostic Criteria for Temporomandibular Disorders instrument (RDC / TMD) ${ }^{(17)}$ and signed the consent form. The study excluded subjects who show signs of psychomotor impairment, performing physical therapy treatment for orofacial pain in the last two years, the presence of cancer disease in the last five years and a history of trauma and/or surgical procedures in the face and cervical spine.

All subjects were informed about the study objectives and procedures performed. The diagnosis of TMD has been enabled evaluator performed by the use of the instrument RDC/TMD (axes I and II). We analyzed 32 patients with TMD diagnostic to identify problems related to sleep, influence of pain on quality of life and parafunctional habits by analyzing responses that belonged to the assessment tool.

The issues examined the RDC / TMD for the sleep were:

Question 20. In the last four weeks, how much have you been anxious or worried: q. By having difficulty falling asleep; aa. By waking up at dawn; bb. Having agitated or disturbed sleep. Both use a scale of 0 to 4 , where 0 is "not at all" 1 's "a little", 2 is "moderately", 3 is "very" and 4 is "extremely".

Regarding quality of life issues were analyzed:

Question 11. In the past six months, how much has facial pain interfered with their daily activities, using a scale of 0 to 10 , where 0 is "no interference" and 10 is "unable to perform any activity";

Question 12. In the past six months, how much has facial pain changed its willingness to participate in leisure activities, social and family where 0 is "no change" and 10 is "extreme change";

Question 13. In the past six months, how much has facial pain changed your ability to work (including housework) where 0 is "no change" and 10 is "extreme change".

Regarding the report of nocturnal oral parafunction was used:

Question 15.c. Have you noticed that you or someone talked range (ringe) or tightens the teeth when asleep? Question 15.e. Do you feel your jaw "tired" or sore when you wake up in the morning? Both used the response options "yes" or "no."

Data are presented as mean and standard deviation. The distribution of the data was analyzed using the Kolmogorov-Smirnov normality test. Correlations Pearson 
and Spearman were applied when appropriate. The alpha error rate of $5 \%$ was considered significant $(p<0.05)$.

\section{RESULTS}

32 subjects were analyzed, 29 women and 3 men, with a mean age of $29 \pm 5.06$ years. Table 1 shows the characteristics of the sample with the scores obtained on issues related to sleep problems and interference of pain on quality of life.

The results obtained in matters relating to sleep and quality of life showed a strong positive significant correlation of the reporting trouble falling asleep with the interference of pain on the willingness to participate in leisure activities, social and family and the ability to work (Table 2). There was also moderate and positive significant correlation of difficulty falling asleep account with pain interference with daily living activities, as well as the report of waking up in the morning and have sleep restless or troubled by the willingness to participate in leisure activities, social and family and the ability to work due to pain. There was a weak positive and significant correlation between reported waking up in the morning with pain interference with activities of daily living.

Regarding the report of nocturnal oral parafunction, $90.62 \%$ of the subjects complained of creaking and clenching of the teeth during sleep, and $78.13 \%$ of the subjects reported feeling tired or sore jaw upon waking in the morning (Figure 1).

Table 1. Scores obtained on issues related to sleep problems and interference of pain on quality of life. $(n=32)$

\begin{tabular}{|c|c|c|}
\hline Variable & Mean & SD \\
\hline Difficulty falling asleep (0-4 points) & 1.19 & 1.23 \\
\hline Wake up in the morning (0-4 points) & 0.91 & 1.03 \\
\hline Have agitated or disturbed sleep (0-4 points) & 1.28 & 1.02 \\
\hline Interference in daily activities (0-10 points) & 2.63 & 2.17 \\
\hline $\begin{array}{l}\text { Willingness to participate in leisure activities, social } \\
\text { and family (0-10 points) }\end{array}$ & 2.09 & 2.39 \\
\hline $\begin{array}{l}\text { Ability to work (including domestic services) (0-10 } \\
\text { points) }\end{array}$ & 1.81 & 2.36 \\
\hline
\end{tabular}

SD: Standard Devition.

\section{DISCUSSION}

In the evaluated cases, low average values were found in the issues related to sleep and quality of life, ie little effect on these aspects of TMD patients studied. However, correlations were observed between sleep-related issues with aspects of the impact of pain on quality of life.

According to Oliveira et al., ${ }^{(18)}$ the chronic TMD patients have some degree of pain impact on their lives. The results showed that the pain in subjects with TMD significantly affected work activities (59.09\%), school (59.09\%), sleep (68.18\%) and appetite/eating (63.64\%). Biasotto-Gonzalez et al. ${ }^{(13)}$ observed in patients with TMD, loss of features like vitality and emotional aspects that influence the severity of the impairment in quality of life. Another study by Oliveira et al. ${ }^{(18)}$ showed that the sleep items (68.18\%) and appetite/eating (63.64\%) were obtained higher percentages of answers related to some degree of impairment in activities of daily living ( $p>0.05$ ).

Still, it has been observed that women with TMD have symptoms of pain, headache, neck pain, teeth clenching and increased pain sensitivity of the masseter, anterior temporal, upper trapezius and sternocleidomastoid, and difficulty

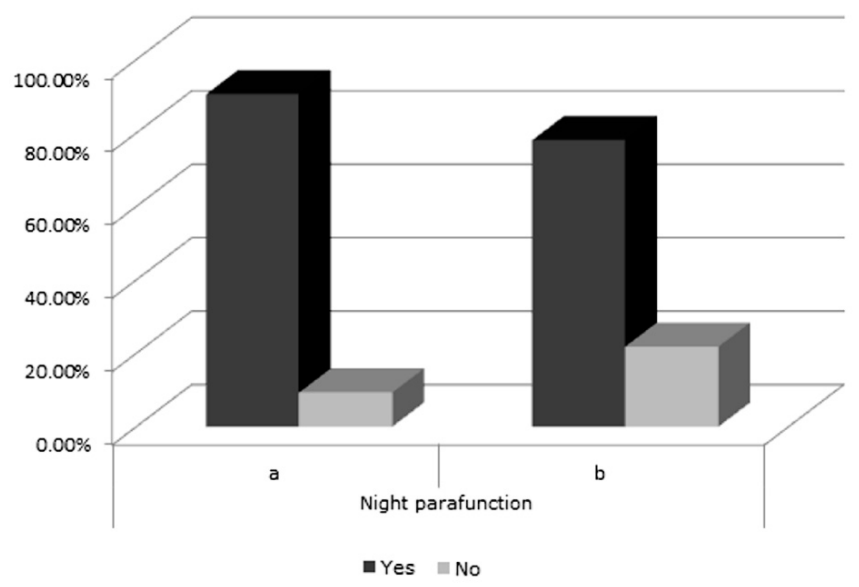

Figure 1. Night parafunction oral report. Night oral parafunction: a. Have you noticed that you or someone talked range (ringe) or tightens the teeth when asleep? B. Do you feel your jaw (jaw) "tired" or sore when you wake up in the morning?

Table 2. Correlation between reports relating to sleep and pain interference in quality of life. $(n=32)$

\begin{tabular}{|c|c|c|c|c|c|c|}
\hline & \multicolumn{2}{|c|}{$\begin{array}{l}\text { Difficulty falling asleep } \\
\text { (0-4 points) }\end{array}$} & \multicolumn{2}{|c|}{$\begin{array}{l}\text { Wake up in } \\
\text { the morning } \\
\text { (0-4 points) }\end{array}$} & \multicolumn{2}{|c|}{$\begin{array}{l}\text { Have agitated or } \\
\text { disturbed sleep } \\
\text { (0-4 points) }\end{array}$} \\
\hline & $\mathbf{r}$ & $\mathbf{p}$ & $\mathbf{r}$ & $\mathbf{p}$ & $\mathbf{r}$ & $\mathbf{p}$ \\
\hline Interference in daily activities (0-10 points) & $0.415^{\mathrm{b}}$ & $0.018^{*}$ & $0.361^{c}$ & $0.043^{*}$ & 0.253 & 0.163 \\
\hline $\begin{array}{l}\text { Willingness to participate in leisure activities, social and family } \\
\text { (0-10 points) }\end{array}$ & $0.620^{\mathrm{a}}$ & $0.000 *$ & $0.411^{b}$ & 0.019* & $0.4509^{b}$ & $0.01^{*}$ \\
\hline Ability to work (including domestic services) (0-10 points) & $0.612^{\mathrm{a}}$ & $0.000 *$ & $0.578^{\mathrm{b}}$ & $0.001 *$ & $0.450^{\mathrm{b}}$ & $0.01 *$ \\
\hline
\end{tabular}

r: Pearson Correlation, *: statistically significant $(\mathrm{p}<0.05)$; a: strong positive correlation; b: moderate positive correlation; c: weak positive correlation. 
sleeping and worse quality of life when compared with women without TMD. ${ }^{(14)}$

Caspersen et al. ${ }^{(19)}$ identified a relationship between the pain of tension head and TMD symptoms, depression, anxiety, sleep problems and impairment of oral functions. It is not clear if the poor quality of sleep leads to headache or otherwise and if the underlying mechanisms of tension headache, TMD and sleep disorders are shared by a common denominator. However, this combination of mechanisms should be examined in the search for appropriate treatment and possible prevention.

Higher frequency of sleep disorders, high pain intensity and psychological disorders found in patients with TMD(20) and these are among the risk factors for the development of TMD. ${ }^{(21)}$

Patients usually present with TMD poor quality of life and, in addition, women show an increased level of severity of this disorder (67.50\%) compared to males (55\%). ${ }^{(13)}$ This was demonstrated in this study on issues relating to the impact of pain on aspects of quality of life (interference in daily activities, willingness to participate in leisure activities, social and family, ability to work including housework). Bernhardt et al. ${ }^{(22)}$ found poorer quality of life in women when compared to men with $T M D$, and this difference was explained by increased pain sensation upon palpation of masticatory and greater impact muscles related to limitations on physical aspects of that due to emotional problems.

Both TMD as the poor quality of sleep can impair the quality of life of these patients. Although there is evidence that the TMD or any other painful condition of the face causing any impact on quality of life, a small number of studies documenting the use of specific tools or even multidimensional tools to this end. ${ }^{(18,23)}$

The changes caused by TMD, especially pain, can interfere with social daily activities of the individual leading to a negative effect on social function, emotional health, and energy level, ${ }^{(21,24)}$ where the chronic TMD frame associated with pain has been associated with changes in the quality of life. ${ }^{(13,22,24)}$

Another factor related to TMD, pain and quality of life is the quality of sleep. The poor quality of sleep or insufficient sleep due to the increased time to fall asleep, awakenings during the night, the presence of restless sleep, among others ${ }^{(25)}$ may result in decreased quality of life and increased perception of pain. Noxious stimuli and painful disorders can interfere with sleep, but sleep disorders also contribute to the experience of pain. Chronically painful conditions are often associated with sleep disorders, as well as increased drowsiness during the day. However, one hypothesis is that sleep disorders cause or modulate acute and chronic pain. Most studies on the effects of sleep deprivation in pain processing reports that sleep deprivation produces hyperalgesic abnormalities that can interfere with the analgesic treatment involving opioid and serotonergic mechanisms of action. ${ }^{(16)}$ There is a reciprocal relationship between sleep quality and pain, but the recognition of disturbed sleep can influence the management of the treatment of painful medical disorders. ${ }^{(15)}$

Regarding the report of parafunction night, most patients in this study reported the presence of symptoms. These habits are seen as important etiological factors in TMD, and one clenching moderate strength of the teeth is strongly related to signs and symptoms of TMJ pain. ${ }^{(26)}$ Thus, it is suggested that patients with TMD have a commitment to quality of sleep. ${ }^{(14)}$

To assess the frequency of symptoms of patients with TMD, Duarte et al., (27) found some parafunctional habit in $62.5 \%, 81.8 \%$ and $100 \%$ in patients classified as mild, moderate and severe TMD, respectively, showing the relation of this habit with the severity of dysfunction. Furthermore, it found that more than $60 \%$ of patients with mild to moderate TMD considered to have a good sleep quality, but $57 \%$ of patients with severe TMD considered as poor. According to Molina et al., ${ }^{(6)}$ clenching is associated with myofascial pain and temporomandibular chewing arthralgia, also may be responsible for pain or tension in the cervical region.

Branco et al., ${ }^{(7)}$ in order to assess the frequency of the reporting oral parafunctions daytime and/or evening in TMD patients, found that $76.9 \%$ of 182 patients studied reported some type of parafunction and may be daytime, night or a combination of both. Daytime oral parafunction was the most frequent among patients with TMD, present in $64.8 \%$ of cases versus $55.5 \%$ of the patients with sleep bruxism reports. The account of both parafunctions was found in $43.4 \%$ of patients with TMD.

The DTM, quality of life, quality of sleep and parafunctional habits are closely related, a comprehensive approach to treating this dysfunction is required. ${ }^{(5)}$ Whereas the sleep deficit can interfere with the processing of pain ${ }^{(15,16)}$ highlights themselves to importance of evaluation and treatment of sleep disorders in patients with TMD. In clinical practice and in the literature, this aspect has been little considered in the DTM approach, should be further explored.

\section{CONCLUSION}

With this study we can conclude that there is an association between sleep-related problems and the influence of pain on quality of life in patients with TMD. The higher the account of complaints related to sleep, the greater the loss of quality of life of the subjects. In addition, TMD patients had a high frequency of nocturnal parafunctional habits, which may be due to poor sleep quality.

\section{AUTHOR'S CONTRIBUTIONS}

CFP: conception and research design, data collection, analysis and interpretation of data, statistical analysis and writing of the manuscript. DP: data collection, the manuscript writing and critical review of the manuscript on the intellectual content. ECRC: orientation of the study, the manuscript writing and critical review of the manuscript on the intellectual content. 


\section{COMPETING INTERESTS}

Nonexistent

\section{AUTHOR DETAILS}

2Physical Therapy department, Distúrbios da Comunicação Humana post graduation program, Universidade Federal de Santa Maria (UFSM), Santa Maria (RS), Brazil.

\section{REFERENCES}

1. Lee M, Choh AC, Demerath EW, Knutson KL, Duren DL, Sherwood RJ, et al. Sleep disturbance in relation to health-related quality of life in adults: the fels longitudinal study. J Nutr Health Aging. 2009;13(6):576-83.

2. Boscolo RA, Sacco IC, Antunes HK, Mello MT, Tufik S. Avaliação do padrão de sono, atividade física e funções cognitivas em adolescentes escolares. Rev Port Ciênc Desporto. 2007;7(1):18-25.

3. Okeson JP, de Leeuw R. Differential diagnosis of temporomandibular disorders and other orofacial pain disorders. Dent Clin North Am. 2011;45(1):105-20.

4. Ozdemir-Karatas M, Peker K, Balik A, Uysal O, Tuncer EBI. Identifying potential predictors of pain-related disability in Turkish patients with chronic temporomandibular disorder pain. J Headache Pain. 2013;14(1):14-7.

5. Conti PC, Pinto-Fiamengui LM, Cunha CO, Conti AC. Orofacial pain and temporomandibular disorders: the impact on oral health and quality of life. Braz Oral Res. 2012;26(1):120-3.

6. Molina OM, Santos J, Mazzetto M, Nelson S, Nowlin T, Mainieri ET. Oral jaw behaviors in TMD andbruxism: a comparison study by severity of bruxism. Cranio. 2001;19(2):114-22.

7. Branco RS, Branco CS, Tesch RS, Rapoport A. Frequência de relatos de parafunções nos sub-grupos diagnósticos de DTM de acordo com os critérios diagnósticos para pesquisa em disfunções temporomandibulares. R Dental Press Ortodon Ortop Facial. 2008;13(2):61-9.

8. Bonjardim LR, Gaviao MB, Pereira LJ, Castelo PM. Anxiety and depression in adolescents and their relationship with signs and symptoms of temporomandibular disorders. Int J Prosthodont. 2005;18(4):347-52.

9. Sipilä K, Mäki P, Laajala A, Taanila A, Joukamaa M, Veijola J. Association of depressiveness with chronic facial pain: a longitudinal study. Acta Odontol Scand. 2013:71(3-4):644-9.

10. Smith MT, Wickwire EM, Grace EG, Edwards RR, Buenaver LF, Peterson $S$ et al. Sleep disorders and their association with laboratory pain sensitivity in temporomandibular joint disorder. Sleep. 2009;32(6):779-90.

11. Baba K, Haketa T, Sasaki Y, Ohyama T, Clark GT. Association between masseter muscle activity levels recorded during sleep and signs and symptoms of temporomandibular disorders in healthy young adults. $J$ Orofac Pain. 2005;19(3):226-31.
12. Turner JA, Dworkin SF, Mancl L, Huggins KH, Truelove EL. The roles of beliefs, catastrophizing, and coping in the functioning of patients with temporomandibular disorders. Pain. 2001;92(1-2):41-51.

13. Biasotto-Gonzalez DA, Mendes PCC, Jesus LA, Martins MD. Qualidade de vida em portadores de disfunção temporomandibular - um estudo transversal. Rev Inst Ciên Saúde. 2009;27(2):128-32.

14. Moreno BGD, Maluf AS, Marques AP, Crivello-Júnior O. Avaliação clínica e da qualidade de vida de indivíduos com disfunção temporomandibular. Rev Bras Fisiot. 2009;12(2):210-4.

15. Moldofsky H. Sleep and pain. Sleep Med Rev. 2001;5(5):387-98.

16. Lautenbacher S, Kundermanna B, Krieg J. Sleep deprivation and pain perception. Sleep Med Rev. 2006;10(5):357-69.

17. Dworkin SF, Le Resche L. Research diagnostic criteria for temporomandibular disorders: review, criteria, examinations and specifications, critique. J Craniomandib Disord. 1992;6(4):301-55.

18. Oliveira AS, Bermudez CC, Souza RA, Souza CMF, Dias EM, Castro CES, et al. Impacto da dor na vida de portadores de disfunção temporomandibular. J Appl Oral Sci. 2003;11(2):138-43.

19. Caspersen N, Hirsvang JR, Kroell L, Jadidi F, Baad-Hansen L, Svensson P et al. Is there a relation between tension-type headache, temporomandibular disorders and sleep? Pain Res Treat. 2013;14(Suppl 1):1-6.

20. Yatani H, Studts J, Cordova M, Carlson CR, Okeson JP. Comparison of sleep quality and clinical and psychologic characteristics in patients with temporomandibular disorders. J Orofac Pain. 2002;16(3):221-8.

21. Selaimen CM, Jeronymo JC, Brilhante DP, Grossi ML. Sleep and depression as risk indicators for temporomandibular disorders in a cross-cultural perspective: a case-control study. Int J Prosthodont. 2006;19(2):154-61.

22. Bernhardt O, Gesch D, Schwahn C, Mack F, Meyer G, John U, et al. Risk factors headache, including TMD signs and symptoms, and their impact on quality of life. Results of the Study of Health in Pomernia (SHIP). Quintessence Int. 2005;36(1):55-64.

23. Biasotto-Gonzalez DA, Andrade DV, Gonzalez TO, Martins MD, Fernandes KPS, Corrêa JCF et al. Correlação entre disfunção temporomandibular, postura e qualidade de vida. Rev Bras Crescimento Desenvol Hum. 2008;18(1):79-86.

24. John MT, Dworkin SF, Mancl LA. Reliability of clinical temporomandibular disorder diagnoses. Pain. 2005;118(1-2):61-9.

25. Associação Brasileira do Sono. Insônia: do diagnóstico ao tratamento: III Consenso Brasileiro de Insônia: 1 ed. São Paulo: Omnifarma; 2013.

26. Carlsson GE, Egermark I, Magnusson T. Predictors of signs and symptoms of temporomandibular disorders: a 20-year follow-up study from childhood to adulthood. Acta Odontol Scand. 2002;60(3):180-5.

27. Duarte LA, Araújo NC, Barreto RC, Batista ALD, Neves RS, Lucena LBS. Avaliação da Prevalência dos Sintomas dos Portadores de DTM Atendidos no Serviço de Controle da Dor Orofacial - HULW /UFPB. Revista de Iniciação Científica em Odontologia. 2008;6(1):1. 